\title{
Jesus and the tyche of Jerusalem: a reflection on the mission of Jesus in Luke 19:41-44 with special reference to the mission of kairos in greek mythology
}

\section{McGlory Speckman ${ }^{2}$}

\begin{abstract}
The paper argues that Luke 19:41-44 has, since the publication of the Kairos Document in South Africa in 1985, been understood in eschatological terms by biblical scholars and missiologists. However, when read as an episode in a long narrative of Luke-Acts which is about the fortune (tyche) of Israel and against the backdrop of the mission of Kairos in Greek mythology, the picture suddenly changes. The episode becomes a watershed point between the rejected ministry of Jesus and the future mission of the church (the Way) which provides countless opportunities to individuals and groups who fail to recognise and snatch the first opportunity presented to them. The conclusion of the paper is that unlike Kairos, son of Zeus who offered a lifetime opportunity to individuals, Jesus, the representative of God offers countless opportunities to all who turn to the Way that leads to him. A foundation for the latter is laid in the gospel while it continues in the Acts of the Apostles.
\end{abstract}

Keywords: kairos; mission in Luke-Acts; contextual theology; biblical interpretation

Recent unsuccessful attempts ${ }^{3}$ at reviving the spirit of the Kairos Document (1985; 1986) by the kairos theologians reveal two things about a kairos ${ }^{4}$. First, it is that there is neither a blueprint that dictates the nature and format

1 This article is part of a work in progress. It deals with one aspect of the on-going research on kairos. A number of aspects such as the origin of the term, its etymology and biblical usage have thus been relegated to the appropriate place in the research and will therefore not be dealt with in this article.

2 McGlory Speckman is a professor in the Department of New Testament at the University of Pretoria. He can be contacted at: m.speckman@up.ac.za

3 For example, Kairos SA "A Word to the ANC in these times (28 December 2011)", Desmond Tutu's threat to pray for the downfall of the ANC government (October 2013), etc. much earlier, a sequel to the Kairos Document, the Damascus Road: Kairos and Conversion (1989) document which focused on violence as the "new kairos" failed to take off for the same reason that recent attempts have not succeeded.

4 My focus is more theological than linguistic. Discussions of a linguistic nature may be followed up in dictionaries, lexica and earlier scholars such as Cullmann, Barr, Russell, Von Rad. Note however, that these still distinguish between Hebrew and Hellenistic concepts of time whereas that distinction is no longer taken for granted these days. Comprehensive works with various aspects of kairos are: the volume edited by Phillip Sipiora, titled: Ancient concepts of kairos., Hans Ramo (2008) "An Aristotelian Human Time-space manifold-from chronochora to kairotopos". Pennsylvania State University. It is clear from these studies that the term was corrupted by about the $3^{\text {rd }}$ century BCE. The LXX is a beneficiary of the corrupted version. 
of a kairos (as per the content of a visitation) nor is it always possible to predict the actual moment. ${ }^{5}$ What works in one context will not necessarily work in another, regardless of it being in the same geographical location. If a kairos happens in response to human circumstances, ${ }^{6}$ it will always be context-bound, therefore, particular. Secondly, Luke's kairos is continually being misunderstood, if not consciously distorted. Owing to the use of kairos in the same sentence as episkopes which renders the interpretation as "visitation" (Suggit 1987a, 1987b), focus has shifted from the content of Jesus' mission which he sums up as the "things that make for peace" to what the Kairos Document referred to as the "moment of truth". ' It appears that some revisionists only understand a kairos in such terms rather than in light of contemporary circumstances and needs.

This in a sense, is a misunderstanding of the nature of mission. For beyond "being sent", a mission has three dimensions, namely, a vision (Nurnberger 1994:119), content and a target. The vision is what urges an individual to act, despite possible consequences (Nurnberger, ibid.). Leading missionaries are known by their zeal (eg. Mother Theresa of Calcutta). The content of the mission is informed by prevalent circumstances in the context ${ }^{8}$ of the mission and the target may be an individual, structure or group of people. In the gospels, the Jewish leaders or the temple system are usually presented as the targets of Jesus' mission. Hence threats to "destroy and rebuild the temple in three days".

At the risk of oversimplifying, even contradicting myself, I would like to take my earlier argument (Speckman, 1993, 1998) further by making a case for the "tyche/fortune of Israel" as the focus of Luke 19:41-44" to which Jesus refers as the "things that make for peace". The gospel narrative sums these up in at least three places, namely, the birth narratives (Luke 1 and 2), Jesus' programme of action (Luke 4:16-18) and Jesus' response to John's disciples (Luke 7: 22) as the content of Jesus' mission. This is in response to a system ${ }^{10}$ that negated the things that make for peace. The

5 In this regard I partially concur with Daniel Carro who postulates that “...our kairoi are only fully apprehended by us retrospectively, never prospectively" (p242).

6 See in Greek mythology why Kairos was expected.

7 Kairos Document, 1985, sub-title

8 See definitions of context in Bates (1998:169), Nolan 1987.

9 This passage is about the lament of Jesus over Jerusalem's failure to recognise the "things that make for peace" and the "opportunity brought about by Jesus' visitation" (my translation and summary).

${ }^{10}$ The term "system" has been used in the South African context to refer to the apartheid system with its different facets. Some New Testament authors have used it with reference to what they referred to as the "Temple Sate System" and Wink uses it to translate kosmos which is the counterpart of God's Kingdom (1993:52 in Bowers and August 2005: 29) 
target is the system of oppression, poverty and alienation with which Jerusalem is associated while the vision is the establishment of God's Kingdom (Luke 22: 29-30 cf Johnson 2011:27). I argue that thus understood, the episode's being placed at the point at which it is in the narrative, represents a watershed point. Jesus looks back at the "temporary" rejection of the content of his mission and then forward to what the future of Israel might entail.

A reflection on the passage in light of the Kairos of Greek mythology ${ }^{11}$ shows that kairos is inseparable from content. It is about the moment at which the content is being delivered. A bad moment or bad timing was referred to as akairos or kakakairos (Sipiora. n.d.). The latter two words are not discussed in this article since the focus is on a different aspect of kairos. The relevance of Greek mythology is that it provides a comparison between Jesus and Kairos, son of Zeus which helps the reader to connect the narrative of the gospel with the Way in the Acts of the Apostles. ${ }^{12}$

My primary aim in this paper is to test the hypothesis that Luke 19:4144 is, according to the narrative, a watershed point in the mission of Jesus to Israel to the extent that the imminent passing of the visitation is founded on the failure of Israel to recognise the moment of her tyche, in this case quantified as the "things that make for peace". This to me is the climax of the episode. A secondary aim is to reflect on how an interpretation of the episode through the eyes of the Kairos of Greek mythology could influence our understanding of mission in Luke-Acts.

The paper proceeds, following this introduction, with a section on the relevance of this exercise for mission. This is followed by an outline of the developmental orientation, quantified as Israel's tyche as reconstructed from Luke 1, 2, 4 and 7. The analysis of Luke 19:41-44 takes place in the third section while a reflection on the passage through the eyes of Greek mythology precedes the conclusion.

\section{Why focus on Luke 19:41-44?}

The approach to the passage as bequeathed to a democratic South Africa by the interpretative framework of the Kairos Document has posed challenges for the understanding of Luke's portrayal of Jesus' mission. It has left an unilinear view which borders on the spirit of Amos' "Yom Yahweh" as opposed to that of Zechariah which portrays a gracious and supportive God.

\footnotetext{
${ }^{11}$ Kairos in Greek mythology is a celestial figure who is a vehicle of fortune. His movements and timing have to be carefully and closely observed so as not to be missed.

12 A reference to the Way in the Acts of the Apostles (Acts 9, 24) picks up the idea of hodos/ way or road at the start of the gospel.
} 
These two positions are represented in modern scholarship respectively by Mowinckel (1954) and von Rad (1959). There may have been good justification for ignoring Mowinckel in both the biblical text and the context of the authors of the Kairos Document. ${ }^{13}$ However, the chosen approach is nevertheless debatable, especially in a democratic context.

A view that is undergirded by the "Yom Yahweh" spirit seems to be in conflict with the main motif of Luke's two-part narrative. The line that runs through like a thread (in Luke's narrative) is that of "promise and fulfillment" which manifests in different ways as the narrative develops. Different points at which this is highlighted will be outlined in the following section. It should be remembered though, that the focus of the Kairos Document was never on the biblical text (Luke 19:41-44) but on the theology that developed around the term kairos. The passage in question emerged during the ensuing debate, in relation to the point made about the combination of kairos and episkopes which renders the meaning "visitation". ${ }^{14}$

Two varying approaches will shed light on why it is important to provide an interpretation of this episode that supports the rest of Luke's two-part narrative. The salvation history approach is the preferred one in this article while the eschatological approach seems to be the preferred approach of the Kairos Document.

\section{Approach from Salvation history}

The notion of promise and fulfilment in Luke-Acts is as old as the works of Conzelmann on Luke's Gospel and Haenchen on the Acts of the Apostles, which date back to the 1960s. ${ }^{15}$ Conzelmann (1960) traced the promises linked to the Old Testament, in particular the prophet Isaiah, from whom Luke drew most of his Old Testament material, and their fulfilment in Jesus. He suggests that Luke intended to write "redemptive history" which is divided into three epochs, namely, the period of Israel (from creation to John the Baptist); the period of Jesus (from John to ascension); the period of the church (from ascension to the parousia) (1960:50). Hence the importance of the link between Luke's story which he sees as the "new Exodus", the Old Testament and the life of the church (cf 1960:137). Conzelmann (1960:23) points out that Luke not only declares the fulfilment

13 Kairos Document analysed the churches and the government of the day and found them equally wanting. See evaluations of the historical impact of the Kairos Document from the perspectives of van der Water (1996) and Mabuza (2009). Given the etymology of the term, there is no correct or incorrect way of interpreting it.

14 See Suggit (1987), Draper and Cochrane (1987), Speckman (1993, 1998).

15 See also a recent take on the theme by another recognised Lucan scholar, Luke T Johnson (2011:23-29) 
of the promises in the birth narratives (Luke 1 and 2) and confirms it through the mouth of Jesus in the Temple (Luke 4:16-18) but also has Jesus place himself in the centre between the prophets and the future (Luke 16:16). In fact, the German title of his book aptly declares Jesus as the "centre of time". ${ }^{16}$ Anything else that happens outside this framework of the fulfillment of promises is a consequence of the rejection of Jesus by the Temple rulers. This includes the persecution and death of Jesus and the eventual opening up of salvation to the gentiles (Acts 28:28).

Three things justify this approach. First, the theology of the entire gospel is about God approaching history in mercy and grace as manifested in the mission of Jesus which Luke sums up well in Luke 4:18-22 and continues to show how it unfolded in practice in the gospel and Acts. Secondly, this divine commitment continues in Acts despite what Jerusalem did to Jesus. Thirdly, Luke in 16:16, the passage Conzelmann refers to as the "centre of time" (Die Mitte der Zeit), makes Jesus declare that God spoke through prophets and others until John and that he was now the one who had come. Was this not a kairos as Zechariah understood it- a theophany and "God interacting with humans on earth?" A comparison of this with other "Day of Yahweh" and related phrases will show that prevalent interpretations of Luke 19:41-44 since the publication of the Kairos Document have been narrow, limited to the prophet Amos and heavily influenced by von Rad's views $(1959 ; 1968)$.

Although there was no unanimity about this approach, publications in the ensuing period indicate that it enjoyed popularity and dominated Lucan studies for a decade and a half. Commenting on developments in the Lucan studies before and since Conzelmann, Von Unnick remarks that Conzelmann's work on Luke and Haenchen's on Acts were "the high - water marks in the rising flood" (1966:16). That there were other approaches found was dictated upon by the specific questions raised by interpreters in different contexts rather than a failure of the paradigm. The approach continues to serve as a tool for those looking for salvation history in the gospel. Hence it was also utilised in the discourse on the term kairos in the aftermath of the Kairos Document.

\section{Eschatological approach}

The debate on the notion of a categorical end-time for a government as a result of its failure to heed the signs of the times prompted Albert Nolan to publish an article on the meaning of eschatology in the Kairos Document (Nolan 1987). In the article, he not only put in perspective what at a

16 The German title of the second edition is: "Die Mitte der Zeit" (1954). 
glance appeared to be a cul de sac position of the document, that is, impending judgement of the church and the apartheid government, but also went on to contextualise the meaning of kairos in this regard. He referred to the "visitations" and the consequences of each in relation to the context of the visitation. He argued that "eschaton" is always in relation to an event in a particular time (1987:61f) otherwise the message of the prophets for example, would have no value effect in any context. In other words, eschatology in this case is not understood in millenarian terms as the end-time but as a succession of eras (Nolan 1987cf Carro, n.d.). Each era comes to an end, leaving either good or bad results. This idea resonates with the definition of kairoi, meaning points at which God breaks into history (Speckman 1993, 1998).

It has to be acknowledged that the prevalent views on kairos rely solely on what has been transmitted from the Septuagint (LXX) down the ages, thus discounting the long and rich history prior to the age of rhetoric..$^{17}$ Apart from the emphasis on the term as one of the words for time, there is also an association of the term with the notion of Yahweh's judgement with the two trajectories as mentioned above. This was promoted by prophets such as Amos, Joel, Zephaniah and to some extent, Malachi as well as some later millenarians ${ }^{18}$ who predicted enddays for wrong-doers. On the other hand, prophets such as Zechariah eased up on the theme of doom while they emphasised God's salvation for Israel. This indicates God's faithfulness to his covenant with Israel. I see Luke-Acts within this framework.

The tendency to automatically associate eschatology with the Amos strand (the latter trajectory) is intended to convey exactly what the prophet Amos has in mind - "doom". Amos has little or no tolerance for the disobedient and he promises "darkness and gloom" (Amos 5:19-20). In the same way, the prophet Malachi promises fire on that day (Malachi 4:1) while Zephaniah dedicates the first chapter of his book to various aspects of God's visitation (Zephaniah 1:1-18). Joel offers a harder blow which focuses specifically on those at the "front", that is, the leaders of the nation (Joel 1:15-2:32). He, like Amos and Jeremiah, focuses on retribution (Amos 5:18f, Jeremiah 46:10).

17 The LXX is known to have influenced the New Testament at least at the following levels: i) shape of language ii) quotations from the Old Testament iii) inspiration for the redaction of New Testament passages (Marcos, NF, 2000:323)

18 Those waiting for the end of time and the coming of Christ's judgement before he establishes the full reign of God. 
Experts on the "Yom YHWH" or "Day of Yahweh" or (later) "Day of the Lord" tradition concur that Amos and Joel were the leading prophets of doom who understood this day to be a doom's day with no chance to escape. Zechariah is one of the prophets who saw the way out as God's mercy and graciousness (Crenshaw 2003). Both views endured throughout the Old Testament period while the positive view seems to have been more dominant between the two testaments and later, New Testament times. This is the view I will emphasize in respect of Luke's theology of the kairos.

The contextual framework provided by the situation of repression and the response of the oppressed majority in South Africa in the 1980s ensured that the theological product of a reflection on the kairos passage would follow Amos' understanding. Nothing less than the eschaton in the sense of the "last days" was expected. That of course was directed at the oppressors and their collaborators, portrayed as the "enemies" of a God who had a special place for the "little ones", the "babes", the marginalised. My aim in this article is to show that Luke's narrative befits more the spirit of Zechariah than that of Amos or Joel. Otherwise his theology of "promise and fulfilment in history" cannot make sense.

\section{Outline of the tyche in the narrative}

This section could be appropriately referred to as a "developmental orientation". In the process of providing an outline of the tyche ${ }^{19}$ (fortune), it also becomes apparent that its content is made up of critical factors in social transformation. The broad term that covers this is "development" ${ }^{20}$ and a Jewish religious term that might convey a closer meaning is shalom. ${ }^{21} \mathrm{I}$ have already argued elsewhere, taking further Cadbury's (1965) remark, that Luke's writings lend themselves to development and I substantiated that with an analysis (Speckman 1999, 2001, 2008). For the purposes of this article I will use tyche or fortune interchangeably with "things that make for

${ }^{19}$ Tyche in this article is used in the sense that it is used in its original Greek context, namely, fortune or luck. I believe that this is the content of the promises Mary had hoped would be fulfilled by Jesus. It is never mentioned in the New Testament while by contrast, kairos is mentioned 80 times. Glenn F. Chestnut (1972:161-162) has advanced a very persuasive argument on the meaning of tyche and why the term was never used by Christian writers, only appearing 3 times in Socrates. I engage him in a different context.

${ }^{20}$ For the purposes of the article, the following definition is preferred: "...creation of conditions that are conducive to the release of a God-given potential" (Pope John Paul V1). Sociologically, the process of creating such conditions is transformation.

${ }^{21}$ Based on Brueggemann's view (1982:18), Bowers \& August (2005:30) posit that "shalom not only means peace in the sense of the absence of strife, but also health, wholeness, prosperity, justice, harmony and general wellbeing". 
peace". The term however, is never used in the New Testament but was prevalent among Greeks, later referred to as pagans.

There are at least three discernible moments for this in the narrative. The Song of Mary (Luke 1), ${ }^{22}$ Jesus' Program of Action, sometimes referred to as his "liberation manifesto" (Luke 4:18-22) and Jesus' response to the disciples of John (Luke 7:22). While these are concentric, each sets its own scene in respect of what is to be expected. For example, in the first three chapters, particular words such as kairos and hodos (Luke 3:4) are introduced right in the beginning in addition to the names of conservative Jewish leaders such as Zechariah (Luke 1:2). Jesus' divine origin is affirmed, not only through a genealogy that traces him to Adam and Eve, then back to God (Luke 3:23-38) but also through a voice that adopts him as God's Son (Luke 3:22) and the host of angels who burst into a song ${ }^{23}$ at the mention of the name of Jesus (Luke 2:14). These unfold as the narrative develops and conflict builds up.

Tyson (1985:43) points out that chapters 1 and 2 do not only set the scene in terms of who Jesus is. They also introduce some of the important themes such as conflict which recur in Luke-Acts. Other connecting points with the rest of the narrative include Luke 20:1-21:38, Luke 1:32 vs Acts $2: 30$, Acts $13: 23,34$. The theme of God's love for Israel which already occurs in prayers and prophecies also includes the expectation that God will save Israel from its enemies (Tyson ibid.53). This finds fulfillment in John (Luke 1:76) and Jesus (1:32; 2:11). However, Tyson (ibid.) makes an important observation that despite all the positive and joyful expectations, Simeon anticipates division, controversy and rejection of Jesus in his second speech. In other words, conflict will be inevitably intertwined with the mission of Jesus. The introduction of Jewish characters such as Zachariah, a priest in the Temple is important because it is the devout Jew who patiently waited for the coming of the messiah and the liberation of Israel (ibid. 49). What happens when Jerusalem rejects the messiah as suggested in the lamentation of Luke 19? I will leave this to the appropriate section in this article.

A reference to "things that make for peace" is found in Luke 19:42. It is part of Jesus' lamentation over what is lacking in Jerusalem. In my view, this refers back to the hopes of the people and the work of Jesus as narrated

22 The place of these narratives in the gospel is contested by a few scholars (see Tyson JB 1992:43). They contend that they were a later insertion and that the gospel originally started at chapter3. For the purposes of this paper, we shall disregard this contention.

23 Augustus Ceasar had declared himself a god and wanted homage to be paid to him. Hence the importance of the adoption (3:22) and the heavenly response $(2: 14)$ which Ceasar did not get. 
by Luke in the first part of his narrative. The three landmarks mentioned above are not just decorations of Luke's story but are an integral part of the story line. Jesus is in conflict with the leaders of his day because of their failure to do what is right by pursuing the "things that make for peace". The authorities of his day are persecuting Jesus because they reject his mission and how he is rolling it out.

If my assertions about the target of a mission are anything to go by, then it should be accepted that the program of Jesus is aimed at correcting the social ills of the day. The first part is introduced with an urgent pointer to the kairos (Luke 1:20) that has arrived. ${ }^{24}$ This kairos is ushered in by the announced coming of Jesus. Thereafter, the term occurs at twelve ${ }^{25}$ other places in the gospel and at nine ${ }^{26}$ places in the Acts of the Apostles. This hints at the importance Luke attaches to the imminence of Israel's fortune and perhaps the need for them to open their eyes to it. For the devout Jew, it is an expectation, not a surprise (Tyson 1992:49). As Farris (1985:115) observes, the infancy narratives have an eschatological significance which at the same time, looks back to the past. Luke achieves this by making use of the aorists which may be pointing to the Christ Event but may also be anticipating what must happen (Farris 1985: 115). They indeed emphasise what must happen and what is expected by and of Israel. The Song of Mary is clear that the birth of Jesus signals a new era, a new epoch for both the ruler and the ruled (Luke 1:51-53). The only difference in her view is that the impending era fulfills the promise they had been waiting for, the promise of a messiah (1:31-33). By implication, the tables will be turned against the oppressor of the poor, the inflictor of pain and the one who meets out injustice against the vulnerable. More importantly, whatever Jesus is bringing about will transform the lives of the people for better. The Anawim $^{27}$ believed this and Mary appropriated it to Jesus. But Israel in return is expected to respond in faith by accepting Jesus. ${ }^{28}$

In order for him to have any legitimacy, any respectable standing, he had to have a credible and traceable line of descent from recognised founding families of the nation (Jeremias(1969), Gottwald (1980), Mosala (1989)). It is therefore no wonder that the genealogy drawn up by Luke (3:23-38), unlike that of Matthew (1:1-16), traces the line of descent back to

\footnotetext{
${ }^{24}$ See the position of the first use of kairos in Luke compared to that in Mark (1:15)

${ }^{25}$ Luke 4:13, 8:13, 12:42. 12:56, 18:1, 18:30, 19:44, 20: 10, 21: 8, 21: 24 and 21:36.

${ }^{26}$ Acts 1:7, 3:20, 7:20, 12:1, 13:11, 14:17, 17:26, 19:23 and 24:25.

27 Anawim refers to a group of poor who placed their hopes in the promised messaiah. They are said to have lived a few years before the birth of Jesus (see Horsley 1989).

${ }^{28}$ Beck lists more expectations. They include fear and wonder, humility, rejoicing, praise, leaping and dancing (1989:59-63).
} 
Adam and to God. If Jesus comes from God, then he himself is God and his deeds are godly. This has implications in the development of the narrative, especially for my approach to the episode under investigation.

The second part consists of Jesus' own declaration of the nature of his mission in Luke 4:18-22. ${ }^{29}$ Although this is an excerpt from a section in the Book of Isaiah (Isa. 61:1-3), by appropriating it to himself as the foundation of his mission and the vision towards which he is striving, Luke's Jesus is in fact, assuming the role of the agent of Israel's prosperity. The passage has sometimes been referred to as a "liberation manifesto" or a "mission statement" (Green and McKnight 1992:502). Others still, have used it as a foundation for the social gospel which addresses the social and economic needs of Luke's audience (Cassidy (1996), Stegemann (1984), Nolan (1977), etc.). This programme finds fulfilment in various ways as it is clear in the examples provided in the response to John (Luke 7:22). However, not all of the aspects he set out to transform were possible to transform during Jesus' life time. The Acts of the Apostles picks these up and turns promises into reality.

Commenting on the passage, Albert Nolan refers to its targets as God's little flock who are sometimes known as the babes, little ones, sheep, poor, etc. $(1977$; 1996). This confirms that Jesus' mission is directed at one target, against another- not at a vacuum. If we look carefully at Luke 4:18-19, we should notice that each intervention has a specific target (the blind, lame, downtrodden, etc.). In the same way, an appropriate response would be expected from each of the targets. In other words, they should be able to recognise the intervention and embrace it in order for it to have an impact in their lives.

In the third place, the specific outcomes of Jesus' programme are seen in the transformation of individual's lives and conditions. Jesus sums these up in his response to John's disciples who are sent to enquire whether Jesus is the expected messiah or not (Luke 7:22). The list includes the restoration of sight to the poor, the healing of the lame, the feeding of the poor. However, the imprisoned are not released from captivity until in Acts when Peter and John (Acts 4:21) are freed by the elders and scribes. Later, the apostles are miraculously freed from prison by an angel (Acts 5:19), Peter's shackles fall off and he is led by an angel out of prison (Acts 12:7-9) and Paul, Silas and other prisoners are miraculously freed from their shackles and the prison doors open (Acts 16:26).

29 The subject of socio-economic conditions and reaction thereto has been dealt with by a number of social historians. These are summed up in my MT Dissertation (1993), 1998 article (R\&T 197-199) and in my DTh thesis (Unisa 1999). 
It would seem that the first part of Luke's narrative is intended to highlight the content of Jesus' mission. This is done through Mary before the birth of Jesus and it is done by Jesus himself. Of course, the narrator also plays an important role in guiding the development of the plot. Towards the end of the first part, the narrator brings Jesus to the entrance of the city, Jerusalem, and makes him "scream" at it for failing to acquire from him what it lacked (19:41-42). I will elaborate on this below. Suffice it for now to point out that at this point already, the foundation for continuity in the Acts of the Apostles has been laid. This again will become clear in my reflection on the episode.

It appears that our view of the phrase: "things that make for peace" has all along been limited by our understanding of "eirene" which only refers to a lack of strife (Bowers \& August 2005:30) or absence of war. It should be much wider and understood in terms of a shalom - a holistic wellbeing of a person. This is certainly what Jesus tried to bring about. Hence his initial mission to correct the faulty aspects of Judaism and to do things God's way.

\section{The watershed moment (Luke 19:41-44)}

It is not my intention to rehash the formalities of textual criticism which have been conducted elsewhere and by a number of people (Marshall 1978, Speckman 1993; 1998). I am working with the text as an episode ${ }^{30}$ in a narrative and my intention is to identify certain elements which make it a "watershed" moment for the story. The clues are suggested in the episode. It must however, be mentioned that the place of verse 44 in the episode continues to be a source of concern although the variants do not suggest a different origin. This is despite Fitzmyer's suggestion that Luke may have borrowed verses 43 and 44 elsewhere and added them to his episode. The problem with Fitzmyer's argument is that he bases his case on the use of kai six times (1985:1253). I am struggling to comprehend its weight. A verse that suddenly brings in retribution for the failure of Jerusalem looks odd in the context of Luke's two-part narrative. ${ }^{31}$ It would be a different issue if there was prior preparation for it in the narrative. The wailing in chapter 13 seems to be making a different point.

${ }^{30}$ I do not agree with the classification of the passage in question as an "oracle" (see Marshall 1978). This creates the impression that it is an oracle against the city in the prophetic fashion. The opposite is intended in this article.

${ }^{31}$ Incidentally, the unity of Luke and Acts has been debated over a long period. There is some consensus that the two documents are the work of the same author (see, eg. Tannehill 1990). 


\section{Uniqueness of the episode}

The uniqueness of the episode to Luke is not in doubt. Even if Mark and Matthew were aware of it (episode), they chose not to use it. Waetjen (1989) argues that Mark's intention with the two fig tree stories on each side of the temple episode was to show the rejection of Israel by God. By contrast, Fitzmyer (1985) and Draper (1991) assert that Luke removed the fig-tree stories used by Mark so he could insert the wailing and indict the temple with a different offense which moved from omission to commission, that is, from a failure to recognize the moment of fortune (19:44) to actively rejecting Jesus $(22: 54,23: 18-22$ cf 4:28, 16:14). Thus they concur with Jervell (1972: 575) who suggests that Luke redacted Mark because it was not his intention to show God's rejection of Israel.

If it were to be argued that Luke redacted Mark in order to fit in a story that appears to be focusing on retribution then it would have to be asked whether the motifs of new beginning and fulfillment have been abandoned at this point of the narrative. It would seem that the prediction of destruction is taken from a different source, perhaps the prophets or it is indeed true that this is a vaticinium ex eventu (that is, it has been composed after the event, the war of 66-70 CE). The position of some scholars such as Taylor (2003) pertaining to an earlier dating of Luke seems to be out of sync with good arguments advanced for putting the date of Mark after the fall of Jerusalem. If Luke wrote after c.70CE, nothing could have stopped him from combining reality with elements of utterances from the prophetic tradition. It is unlikely that he was quoting Jesus verbatim.

I have already indicated that in my view, the episode is not an ordinary oracle. It is rather a lamentation (Speckman 1993, 1998). It employs the style used by the prophets of old who wailed and used funeral dirges to highlight the gravity of the charges against Israel. The author has Jesus crying out: “...Would that you knew..." (Luke 19:41). ${ }^{32}$ This is similar to a more direct cry: "oh Jerusalem! Jerusalem!..." (Luke 13:34-35) where Jesus longs to put Jerusalem under his wings although the emphasis of each is different.

In the first instance however, Jesus is not as explicit about his disappointment at the failure of the city to recognize his mission and its content. He is still offering his life and willingness to nurture the city. Hence the metaphor of a hen with spread-out wings. This however, is no reason for us to assume that if he gave them this chance in the first instance, he is then taking it away during the second occasion. It could

32 I am consciously putting it as an incomplete sentence for I think that the exclamation ("oh Jerusalem!") may have been lost in the translation 
only be pointing to a change of tactic -from speaking gently to using harsh words without intending to cause harm. Luke was influenced much by the Old Testament and he drew a lot of material from it (Marcos 2000:322). The reader should therefore not be surprised if he appears to place Jesus in the tradition of the prophets, employing their tactics (without necessarily following the Amos trajectory).

\section{Scene of the episode}

The scene is set outside Jerusalem, apparently close to the entrance (19:41). There is no consensus about the proximity of the spot where Jesus stood. It is clear however that it was not Mount of Olives because he had already descended from there (19:38). Caird (1972:216) postulates that Jesus stands outside that city to inspect it in the same way a general would inspect his army. This, he argues, is based on the Old Testament view that Yahweh would do the same on the "Day of the Lord".

I do not agree with the above explanation for the reasons advanced in my discussion of the eschatological approach above. Instead, my view is that Jesus would have been just outside the entrance to the city (19:41). It is possible that the spot chosen was elevated above the wall, allowing the speaker to see the city which he was addressing (19:37). This is suggested by the accusative "you..." (19:42,) - it is as if he is looking at the addressee as the target of his words and levelling the accusation directly at it. The alternative is that he would be addressing the walls, which is inconceivable.

\section{The respondent(s)}

It is not obvious in the text to whom reference is being made. One school of thought suggests that it is made to the entire city, this being based on the prediction of a destruction in verse 44 (so Taylor 2003:298, Fitzmyer 1985:1257 cf Evans 1990:685). The other school of thought points to the leadership of Jerusalem, this finding its origin in two places - namely, the reference in Luke 19: 44 to the failure to recognise the hour of visitation and an earlier reference to things that are only revealed to the humble (10:21). It should be borne in mind that in 7:16, there appears to be a deliberate contrasting of the leaders and the people - it is the ordinary people, the crowds who remark that "God has come to visit" (7:16) while there is no mention of the leaders. The wailing is of course, a monologue.

In my view, the target is neither the temple nor its rulers but the system that is administered from the temple. Jerusalem represents a system which is operated from the temple. It is this system that must be destroyed through a substitution for the things that make for peace. Brueggemann (1982:18) 
unambiguously states that the absence of shalom leads to social disorder of economic inequality, political oppression and exclusivity (in Bower and August 2005: 30). The war that incidentally befell the city was of a political nature, a culmination of the long-standing tensions between the Jews and their Roman masters. This is not in line with the mission of Jesus throughout which he avoided anything that would attract unnecessary attention from the Roman authorities (see Luke 20:25).

\section{Conflict}

There is definitely a conflict implied in what is not being said overtly in this episode. This is in terms of the plot of the story as well as the social conditions that the story seeks to portray. The first pointer to the conflict is the accusation pertaining to a lack of peace in Jerusalem (19:43). This suggests that there is internal strife which causes instability although not necessarily war at this stage. The internal conflict is possibly between the different social groups found in the city which include, in terms of the broader narrative, devout Jews, temple rulers, poor people, rich people, Gentiles, outcasts and rebels. A cursory look at these groups reflects disparate interests thus providing a prima facie case of conflict. It should however, be noted that Jesus is not saying that there is no peace but more fundamentally, that the ingredients that make for peace are non-existent. Given the variety of groups mentioned, it should not be difficult to guess that the lack of prosperity and social justice are at the centre of the conflict (Brueggermann 1982:18, cited in Bowers and August 2005:30). ${ }^{33}$

In other parts of the gospel, up to this point, Jesus seems to be having a conciliatory attitude towards Roman authorities (see 20:25) while he is harsh on Jewish leaders (eg.11: 37-52, 12:1-21).

The second type of conflict is born of the rejection and persecution of prophets. Jesus in Luke is a victim of this kind of conflict. Two examples that are related to the mission that I have outlined above are his being thrown out of the temple, actually led to the parameter of the city to be killed (Luke 4:29) after declaring his mission. The perpetrators in this case are the temple authorities. In Luke 8:37 Jesus is asked, this time around, by the villagers to leave because he exorcised demons, not because, as often assumed, he sent them to a herd of swine. The village, the narrator tells us, was "seized with great fear" because of the powers that were in him. Luke 19:41-44 signals the last stage of his mission and shows more pity for their ignorance than anger.

${ }^{33}$ For a summary of different scholarly reconstructions of the socio-economic situation see my previous article in the Journal of Religion and Theology (1998:197-199). 


\section{Theme, climax and anti-climax}

Luke has already provided an overview of the tyche in the preceding chapters of the narrative. The tyche in this context is consciously used as the synonym of eirene (peace). It is the theme of the episode and it links up with the theme, if not one of the themes, of the entire narrative. Israel prayed for shalom and Jesus was, in the words of Mary (Luke 1) and his own (Luke 4), that agent who would bring about the long awaited prosperity (shalom).

If the story contains the actual words of the main character, then clearly, the main character of the story was not thinking of war but the internal unstable situation. The ingredients ${ }^{34}$ of peace also make it obvious that external attacks could not have been what was envisaged because the ingredients mentioned would not apply to external attackers, even as insurgents. The tyche (in this case, that which makes for peace) is thus the climax of the episode.

The context of the tyche is suggested by the statement pertaining to the lack of things that make for peace. It should be remembered that Jesus in Luke 19:41-44 is nearing the end of his mission and that he is reflecting on the reception he has had. To understand what that is, one has to go to-and fro- in the narrative. Strangely, according to the evidence, Jerusalem did not see it despite it glowing in front of her.

I had earlier averred that the episode in question constitutes Jesus' evaluation of his rejected mission. I also proceeded to assert that this serves as a watershed point in that it provides a looking back as well as a looking forward. We also already looked back at the path Jesus has travelled, the rejection of his mission and the failure to recognise who he was. What has transpired thus far refutes even Albert Schweitzer's (1959) thesis of a failed revolution, depending on what is meant by revolution. In fact, Conzelmann (1960:139) argues that the choice of the title "king" for Jesus showed that there was nothing political about his program.

Clearly, Jesus did not get the authorities to adopt a completely new way of doing things, that is, a complete turnaround. However, there is no sign that he went to Jerusalem with the intention of seizing political power (Yoder 1972). Luke makes the point very clearly, that Jesus is not the one who failed in his mission but that Jerusalem rejected him out of ignorance by failing to recognise him (19:44). The last verse of the episode is therefore an anti-climax.

34 The word is preferred to "components" as it conveys exactly what is meant here, "the activity of mixing and putting together things that make for peace" while "component" sounds static. 
There can be no doubt, given the above discussion, that Luke in 19:41-44 intended to highlight the disappointment of Jesus at the failure of Jerusalem leaders to embrace the tyche which is the content of his mission. However, in order for the reader to appreciate what it is, there has to be a backward journey to the beginning of the narrative where the scene for the rest of the narrative has been set. It is when that has happened that the reader realises the problematic nature of verse 44 in the narrative. The hopes rekindled by the birth of Jesus in the beginning of the narrative (Luke 1\&2) cannot end up in a curse (vs 44) against a city which is clearly not collectively culpable. ${ }^{35}$ Devout hopefuls such as Zechariah and Simeon could not have hoped for the messiah who would turn against the city rather than deliver it from Roman oppression (cf Tyson 1992:49) unless they too grossly misunderstood the meaning of the coming messiah. Jesus focused on overhauling the temple system first but experienced strenuous resistance in his attempts to dislodge the system. Hence he chose to operate outside it. If he uttered the words in verse 44 in the spiritual sense of destroying the system, then the destruction of the city during the war of c.66-70 CE is that which gave the words a literal meaning. His words may have even been tempered with and details tailored to the events during the war.

\section{Jesus, Kairos and Mission}

How can the above assist us in understanding the mission of Jesus better? If attention is moved away from kairos episkopes to Kairos the character, it leaves the episode with the ignorance about the "things that make for peace" as the issue (19:42). We have established above that the meaning thereof is essentially about the fortune or luck or tyche. In Greek mythology this was personified in Kairos, son of Zeus. ${ }^{36}$ We need to ask whether in highlighting the content of Jesus's mission (in all aspect of mission as summarised in the introduction to this paper) as he has done was not in a sense also countering prevalent ideas about Kairos the hero of ancient Greeks who was apparently still popular during the second century in the Common Era. For example, a relief which is currently kept at the Museum of Antiquities of Turin in Italy (see John Tzetzes) dates back to c.160 CE. It depicts the Kairos. Chestnut (1973:161) assumes that this was the case

${ }^{35}$ If this was not the case, Luke would not constantly and deliberately distinguish between the different groups.

36 The information used about Kairos has been taken from the poem of Posseidipos, the volume titled: “Ancient concepts of Kairos “, the Greek Fables and Ramo's work on Aristotelian Human Time-Space. In order to avoid too much repetition as all accounts seem to be saying the same thing, a summary has been provided without relevant individual references. Such details are provided in the more detailed on-going research. 
because Christians wrote about cosmic powers behind things. Fortune (Tyche) was apparently seen by the Greeks as the fortuitous element in history (1973:162). It is apparently Socrates who highlighted kairos as the cosmic power that exuded sympathy towards humans while Eusebius, only in the fourth century, began to use the language of tyche a lot more in his Christian philosophy (1973:162).

If such views about Kairos were prevalent in Luke's time, it is possible that the author would then be portraying Jesus in the same manner as he had done with Ceasar and the miracle workers of his time, that is, as something more than them (Luke 9:49-50). Even if this is not the case, we may, based on the continuation of the narrative in the Acts of the Apostles, make sensible comparisons for the mission of the church.

Kairos who is caricatured in the form of an eighth century statue ${ }^{37}$ is said to have a bald head with a tuft of hair hanging at the front; is naked with feet that are fitted with wings; he carries a sharp razor in his right hand and appears, then disappears again in a split second. Initially, his mission was understood to be to bring fortune to individuals. However, the removal of the bronze statue from the obscurity of its sculptor' ${ }^{38}$ porch to the entrance of the Olympic ${ }^{39}$ stadium suggests that the list of beneficiaries per visitation was expanded. It was no longer individuals but groups or teams who went into the stadium.

\section{Four factors are of significance for this article:}

First, Kairos was thought to be appearing to the beneficiary once in a lifetime then disappearing quickly. If individuals, particularly those in need were not living in the "spirit of expectation", they would miss that lifetime chance. Hence the importance of being able to read the signs of the times (Nolan 1987:118). In fact, the significance of nakedness and bald head was that if he was not confronted from the front (or caught by the proverbial tuft), it would be impossible to do so from behind as he was "passing by" very rapidly. Recognising the approaching opportunity was crucial.

Could it be that the "passing by" of Jesus in Calvary was seen in the same manner? This again is where the episode provides a clue: "Would that even today you could recognise the things that make for peace"

${ }^{37}$ Information about his features is contained in a poem by Ion of Chios. Other sources used are: Aesop, Greek Fables C.6BCE, Pausanias, Greek Travelogue C.2CE and Callistratus, Greek Rhetoric C.4CE.

${ }^{38}$ Said to be Lyssipos of Sikyon

39 There is a theory about two alters on each side of the entrance of the stadium, one dedicated to Kairos/Opportuity and the other to Hermes of the Games (Pausanias, Description of Greece 5.14.9). 
(vs42). Kairos does not create such a space because in the first place, he does not have a set "package" but delivers according to the individual's needs. Jesus by contrast has a set "package", a framework, because what he delivers must lay a foundation for the Kingdom (God's Rule) which is his ultimate vision. The content of his mission must create a framework for transformation towards this (Bowers \& August 2005:3032). In the second place, Kairos neither has a democratic spirit nor patience. He does not ask what the beneficiaries need. Nor does he wait for them to be ready for him. He moves on regardless. The consequence is that individuals remain indefinitely in their situation of need if they miss him when he first appears.

Secondly, the duration of his visitation is very short. He is no 'friend of men' so he does not live among people. Hence he must move like lightningappearing and disappearing as quickly as he had appeared. Jesus, according to the narrative, lived among people-was even registered in their records as one of them (Luke 2:5, 21, 22-24) although his divine identity was only revealed in the last three years of his life. It is because of this that Gregory of Nazianzus could declare: "what has not been assumed has not been healed " (Epistle 101) or "saved". If anyone was tempted to compare the two, Luke obviates that by making it clear that Jesus lived in the flesh, could empathise as well as be overcome by indignation when necessary (19:42). Three years is still relatively short and it could be compared with the swiftness of Kairos' movement. However, Jesus was the victim of human conflict whereas Kairos, the remote one, could not be affected by human conflict as he was not one of them.

Thirdly, the position of the tuft of hair, the bald head and the naked body make Kairos elusive. There is no part of the body or clothing to grab him by. Whether these represent what is in the human mind about the behaviour of this young god or the mind is conditioned by the features of the statue, Luke obviously wishes to provide a different picture in his narrative. Indeed, the intended beneficiaries neither recognised nor embraced the fortune he brought them. This is already suggested at Luke 12:56. With his "passing by", they would have also missed a lifetime opportunity if Kairos were to be used as the standard. However, Luke was soon going to show through the teaching of Jesus in the temple (19:4521:38), and the Emmaus road appearance (Luke 24:15), that they did not forfeit the privilege of future opportunities.

Fourthly, Kairos is throughout, portrayed as the God of Luck, a male version of Fortuna or Eutyche, the Goddess of Luck. Luke consciously and constantly portrays his chief character, Jesus, as an individual on a purposeful journey (Luke 4: 18-22) who is calling others 
to a feast that is already prepared for them (Luke 5:11, 27, 9:59). It is not by chance that they must participate but by choice $(7: 44 b-48,9: 23$, $19: 8-9$ cf 12:56, 19:42). He is not bringing them "luck" but a total and sustainable transformation of life. This is more than luck but fortune in the sense of a "treasure".

In flesh and blood he confronted them face to face. When he was not accepted, he turned around and moved on. Owing to the fact that he had already laid the seed for the Kingdom, had given them a framework for it and established an inner group of people to continue as foot-soldiers, he invited all as he had done when he first called his disciples, to come after him on the Way (Acts 9:2, 22:4). This time around, it is not only for what people can gain from him but also for the role they can play in the advancement of God's Kingdom (Luke 9:23). He will not be elusive because he is not Kairos. However, he will only be accessible to those who earnestly seek him by keeping to the Way (Acts 1:3-4). The clue to this is already found at the end of the first part of the narrative when Jesus appears to travellers on their way to Emmaus (Luke 24:15, 30,36). It will no longer be those from the house of Israel who are welcome to do this but all who believe in his mission and embrace it (Acts 28:28, see also hints in the healing miracles as well and Jesus' visits in non-Jewish homes).

\section{Conclusion}

The democratic context of the present interpretation of Luke 19:41-44 has removed the urgency to "speak truth to the powers" that be. At the same time, it allowed me to explore an alternative reading for the ongoing mission of the church. The result is an interesting possibility that needs further exploration by biblical scholars. It does not remove the responsibility of holding the powers that be accountable but challenges those on a mission to also actively play their role in bringing about the tyche which is the basis of the Kingdom. No Kairos or Fortuna will make a stop - by but Jesus who gave them the formula will lead them towards a better place if they follow in his Way. This is not a depoliticisation of kairos but an experimentation with a more radical reading of the passage in a democratic context. The use of the term in the Kairos Document follows the framework of the document that was used in addressing Lenin's regime. It is hoped that the foundation laid by this paper will lead to an alternative approach to the church's intervention in the current situation. Instead of pointing out what is wrong, the church should now highlight what needs to be done (the tyche of the moment) and work towards it. 
The following is clear, even with the above-presented tentative reading of the narrative:

- Mission has a vision, content and target and the mission of Jesus was, in Luke's view, no different

- The view of kairos as presented in the Kairos Document is context- bound, not universal. It is based on the LXX translation of the Hebrew (eth and mo-ed) terms for time. There is no focus on a specific (kairos) biblical text save Romans 13

- In line with the content aspect of mission, it has become clear in this reading that contrary to what I had argued before (Speckman 1998), kairos in the context of the mission of Jesus does have a basic framework, the tyche or things that make for peace for these lay the foundation (by transforming recipients) for the Kingdom which Jesus seeks to establish. It is this which becomes a kairos in the normal course of events and a crisis when it is absent. Christians are called upon to pursue it. A criticism of the authorities must be countermanded with introspection to see if Christians are themselves playing their role in advancing the Kingdom.

- It is possible that Luke also had to deal with contending views such as comparing Jesus with Kairos of Greek mythology. In that case, his view of Jesus who is leading on the Way, leaves no doubt in the mind that Jesus is no son of a god. It should be remembered that Luke did the same in relation to Ceasar and other figures in the Acts of the Apostles. He put them in their places.

- Finally, it should be asked whether the primary purpose was achieved and whether there is a clear watershed. To the extent that Jesus looked back with disappointment and started off in the direction of the cross, the dividing line being failure to recognize the tyche of Jerusalem, the primary purpose has been achieved. A pursuit of the tyche should now become the basis of Christian social action and the church's mission in general.

Having said this, the invaluable contribution of the Kairos Document to the manner in which the church plays its role in the world cannot be downplayed. It is because of this that the church, not only in South Africa but also in the Americas and Europe, is able to earnestly and honestly take stock from time to time. 


\section{Bibliography}

Barr, J 1962. Biblical words for time. London: SCM

Bate, S.C. 1998. Method in Contextual Missiology. Missionalia ,26(2): 150185.

Beck, B.E 1989. Christian character in the Gospel of Luke. London: Epworth.

Bible: Revised Standard Version and Good News Bible with Apocrypha.

Bowers, N. \& August, K.T. 2005. Transformation as Mission : moving from Development to Social Transformation. Missionalia, 33(1):20-34.

Brueggemann, W. 1982.Living toward a vision: Biblical reflections on Shalom. New York. United Church Press. In Bowers, N. and August, K.T. 2005.

Cadbury, H. 1965. President's remarks at the opening of the New Testament Society Congress.

Cassidy, R. J 1986. Jesus, politics and society. Maryknoll: Orbis.

Caird, G.B 1972. St Luke. Middlessex: Harmondsworth

Chestnut, G.F 1973. Kairos and Cosmic Sympathy in the Church Historian Socrates Scholasticus. Atlas library. Paper presented on 10 February at a meeting of the Midwest Patristics Seminar in Chicago.

Cochrane, J.C \& Draper, J.A 1987. A response . The word in the words: Hermeneutics. JTSA. 60:75.

Cochrane, J.C \& Draper, J.A 1987. The parting of the ways. JTSA, 59:76.

Conzelmann, H 1954. Die Mitte der Zeit. Studien des Lukas. Tubingen: Mohr.

Conzelmann, H 1960.The Theology of St Luke. London: Faber \& Faber.

Crenshaw, J.L 1995. Theology in the Book of the Twelve. In. eds Redditt, P.L and Schart, A. Thematic threads on the Book of the Twelve. Berlin. De Gruyter: 175-191.

Cullmann, O 1962. Christ and time. London: SCM.

Draper, J.A 1991. "For the kingdom is inside of you and it is outside of you: Contextual exegesis in South Africa". In Hartin, PJ \& Petzer, JH (eds). Text and interpretation: New approaches in the criticism of the New Testament: 235-257. Leiden: Brill. 
Farris, S. 1985. The hymns of Luke's infancy narratives. Origin, meaning and significance. $J S N T, 9: 115$.

Fitzmyer, J. A 1985. The Gospel according to Luke (X-XXIV). Garden City: Doubleday

Green, J.B. \& McKnight, S. (eds) 1992. Dictionary of Jesus and the Gospels. Illinois. Intervarsity Press: 501-503.

Gottwald, N. K 1980. The tribes of Yahweh: a sociology of the Jewish revolt against Rome AD 66-70. Cambridge: Cambridge University Press.

Haenchen, E 1979. The Acts of the Apostles: A commentary. Oxford: Blackwell.

Hodges, Z.C. \& Farstad, A.L. (n.d.) The Greek New Testament according to the Majority text. Nashville: Thomas Nelson Publishers.

Jeremias, J 1969, Jerusalem in the time of Jesus. London: SCM.

Johnson, L.T. 2011. Prophetic Jesus, Prophetic Church. Grand Rapids: Eerdmans.

Kairos Document. 1985. Johannesburg: Skotaville.

Kairos SA, 28 December 2011. A word to the ANC in these times (a letter addressed to the ANC on the Eve of the Centenary Celebrations of its existence).

Kurz,W 1999. Promise and Fulfilment in Hellenistic Jewish Narratives. USA: Trinity Press International .In Moessner, D.P(ed) Jesus and the heritage of Israel:147-170.

Marcos, NF. 2000. The Septuagint in Context (translated y WGE Watson).Leiden: Brill.

Marshall, I.H. 1978. The Gospel of Luke. A commentary on the Greek Text. Exeter: Paternoster Press.

Mabuza, W.M. 2010. Kairos revisited: investigating the relevance of the Kairos Document for church-state relations within a democratic South Africa. PhD thesis. UP

Mosala, I.J. 1989. Biblical Hermeneutics and Black Theology of Liberation in South Africa. Grand Rapids. Michigan: Eerdmans.

Mowinckel, S. 1954. He that Cometh. Oxford: Blackwell.

Nolan, A 1977. Jesus Before Christianity. Cape Town: Phillip.

Nolan, A 1987. The Eschatology of the Kairos Document. Missionalia 15:61-69. 
Nolan, A and Broderick, R 1987. To nourish our faith: Theology of liberation for Southern Africa. Benoni: Rogley Printers.

Nurnberger, K. 1994. The task of the Church concerning the Economy in a Post-Apartheid South Africa. Missionalia 22(2): 118-146.

Russell, D.S 1964. The message and method of Jewish apocalyptic: 200 $B C-100 A D$. London: SCM.

Sanders, J.T 1987. The Jews in Luke-Acts. UK: Fortress.

Sheed \& Ward. 1971. The Septuagint in the Gospels

Smith, J.E 1969. Time, Times and the "Right Time". Chronos and Kairos. The Monist 53(1):1-13. In Ramo, H 2008. Pennsylvania State University. http//tas.sagepub.com@Pennsylvania State University. April 10. 2008.

Speckman, M. 1993. Kairos Document and the Development of a Kairos Theology in Luke. MTh dissertation (in partial fulfilment). Natal.

Speckman, M. 1998. The Kairos behind the Kairos Document. Religion \& Theology 5(2):195-221.

Speckman, M. 2008. A Biblical Vision for Africa's Development? Pietermaritzburg:Cluster Publications.

Stegemann, W. 1984. The Gospel and the poor. Philadelphia: Fortress.

Suggit, J.N 1987. Kairos: wrong way on the right road. JTSA. 58 (70-74).

Suggit, J.N 1987. Kairos. Words or the Word? JTSA. 60 (73-75).

Taylor, N.H 2003. The destruction of Jerusalem and the transmission of the Synoptic eschatological discourse. HTS: 59(2).

The New Interpreter's Bible. 1995. Nashville. Abingdon Press (vol. IX).

Tiede, D.L. 1988. Augsburg Commentary on the New Testament Luke. Minneapolis: Augsburg Publishing House.

Tyson, J.B. 1992. The Jewish people in Luke-Acts. NTS 30 (574-583).

Van der Water, D.P 1998. The legacy of a prophetic moment: a sociotheological study of the concept and the response to the Karios Document amongst churches for the communities and individuals in South Africa and within the international ecumenical community focusing on the English-speaking churches in South Africa with special reference to the United Congregational Church of Southern Africa. $\mathrm{PhD}$ thesis. University of Natal. 
Von Rad, G. 1959. The origin of the Day of Yahweh. JSS 5:97-108.

Von Rad, G. 1968. The message of the prophets. London: SCM.

Van Unnik, W.C 1966. Luke-Acts. A storm-centre in contemporary scholarship. In Kerk, L and Martyn, J.L Studies in Luke-Acts. Britain: Abingdon.

Waetjen, H.C 1989. A reordering of power. A socio-political reading of Mark's Gospel. Minneapolis: Fortress.

White, E.C 1994. Kairos. In Macey, S.L (ed) Encyclopedia of Time. New York: Garland Publishing House.

Yoder, H 1972. The politics of Jesus. Vicit agnus noster. Grand Rapids: Eerdmans. 